Jurnal Keperawatan Padjadjaran

ISSN 2338-5324 (print)

ISSN 2442-7276 (online)

Online di http://jkp.fkep.unpad.ac.id

DOI : $10.24198 / \mathrm{jkp}$

\title{
Perceived Stigma, Psychological Response, and Nurse Coping In The Covid-19 Pandemic In Indonesia
}

\author{
Fitria Endah Janitra ${ }^{1}$, Erna Melastuti ${ }^{2}$, Ah Yusuf ${ }^{3}$, \\ Harif Fadhilah ${ }^{4}$, Yan Adi Wibawa ${ }^{5}$ \\ ${ }^{1,2}$ Universitas Islam Sultan Agung, Semarang, Indonesia, ${ }^{3}$ Universitas Airlangga, Surabaya, Indonesia, \\ ${ }^{4}$ Universitas Muhammadiyah Jakarta, Tangerang, Indonesia, ${ }^{5}$ RS. Dr. Kariadi, Semarang, Indonesia \\ Corresponding Email: fitria.janitra@unissula.ac.id
}

Received: 20-11-2020 Revised: 13-02-2021 Accepted: 15-02-2021

\begin{abstract}
Nurses are at the forefront of being directly involved in the care of Covid-19 patients. This can put nurses in a difficult position, especially if they had lack support from the surrounding environment. The society's negative stigma towards nurses can trigger psychological problems for them. Good coping is needed to maintain the work performance of nurses. This study aims to identify the perceived stigma, psychological response, and coping of nurses involved in caring for Covid-19 patients in Indonesia. This research was a cross-sectional study based on an electronic survey. The number of respondents was 509 nurses who came from all regions in Indonesia on 11-20 April 2020. Respondents were nurses who handled Covid-19 patients directly. The data were collected using a modified questionnaire the Berger stigma scale, DASS and Brief of Cope with a total of 27 questions. The questionnaires used have been proven valid and reliable after being tested on 30 nurses treating Covid-19 patients with a Cronbach Alpha value as follows: modified Berger Stigma Scale 0.952; modified DASS 0.928; and modified Brief of Cope 0.753 . Most respondents were 26-35 years old $(52.1 \%)$, female $(61.5 \%)$, and worked in governmentowned hospitals (48.3\%). 231 respondents were stigmatized $(45.4 \%), 274$ respondents were depressed $(46.2 \%)$ and 209 respondents experienced stress (41.1\%). The majority of respondents chose problem focused coping $(65.8 \%)$. This study shows that some respondents feel they were stigmatized by society, but they have good coping (problem focused coping) to reduce their mental burden. Negative stigma against nurses is often difficult to avoid. Support from family and colleagues was something that can ease the mental burden of nurses. Support from the government was needed to educate the public so that it does not give negative stigma to nurses and other health workers.
\end{abstract}

Keywords: Coping, Covid-19, nurses, stigma. 
Fitria Endah janitra: Perceived Stigma, Psychological Response, and Nurse Coping in The Covid-19 Pandemic

\section{Introduction}

Since December 2019, the city of Wuhan in China has reported cases of pneumonia caused by a new type of corona virus, namely Covid-19, which has now spread throughout the world (Li et al., 2020). Currently, there are 213 countries and territories affected by Covid-19 with almost 21 million cases, and 768,969 of them died (Worldometers.info, 2020). Per 15 Agustus 2020, the number of cumulative positive cases in Indonesia reached 137,468 with 6,071 fatalities (Satgas Penanganan Covid-19, 2020). In May 2020, there were more than 230,000 medical workers contracted with Covid-19 and more than 600 nurses died from the virus in 79 countries around the world. Whereas in Indonesia, as of August 1, 2020, 153 health workers died from Covid-19 and 55 of them were nurses. This makes Indonesia the country with the second highest death rate for health workers in Southeast Asia.

Coronaviruses are a large family of viruses that cause illness ranging from mild to severe symptoms. The virus that causes Covid-19 is called Sars-CoV-2. Transmission comes from close contact and droplets of the patient. About $44 \%$ of infections are thought to occur before symptoms appear (He et al., 2020). It is estimated that about $86 \%$ of infections remain undocumented, and about $55 \%$ of cases are contagious. This may be due to the period of infection that precedes symptoms, the frequency of asymptomatic cases, and the poor sensitivity of nasopharyngeal RT-PCR (Siordia, 2020).

Facing this pandemic situation, health workers are at the forefront of being directly involved in the diagnosis, treatment and care of Covid-19 patients who are at risk of experiencing psychological distress and other psychological health symptoms (Ornell et al., 2020). The increasing number of confirmed cases, high workload and limited personal protective equipment, and lack of support have made the mental burden of health workers even heavier (Chew et al., 2020). The increase in Covid-19 cases has caused many workers who work in the health sector to be exposed to this virus, one of which is a nurse. It is not uncommon for nurses to experience stigmatization from the community.
Erving Goffman defines stigma as a phenomenon when an individual with certain attributes that is highly discredited by society is rejected or excluded as a result of these attributes (Goffman, 1963). Stigma is a process whereby the reactions of others negatively affect a person's normal identity. The existence of stigma felt by nurses causes various mental health problems including stress, anxiety and even depression which can affect the quality of their work. Quality of work life is a reflection of the satisfaction of the nurse which has implications for several dimensions of life of the nurse, among the lives at home, the work environment, working conditions and the nurses' perception about their work (Somantri \& Yudianto, 2018).

Nurses suffer from stigma from society as they work in hospital environments, a highrisk area for SARS-CoV-2 contamination (Koh et al., 2005). Stigma is associated with violence against healthcare workers: more than 200 attacks on healthcare workers and health facilities during the ongoing pandemic had been reported by May 2020 (Bagcchi, 2020). Healthcare workers were denied access to public transport, insulted in the street, evicted from rented apartments, and even physically assaulted. In Indonesia, there was refusal of the bodies of nurses who were confirmed to be Covid-19 and expulsion from their homes due to the fear of local residents (Elvina, 2020; Suyudi, 2020).

During the Covid-19 pandemic, the prevalence of depression and anxiety was high (Zheng et al., 2021). Anxiety is common among health care workers who are directly involved in managing affected patients during pandemics (Spielberger, 2010). Causes of anxiety among nurses include a lack of personal protective equipment and a concern that they can carry infections from the work environment to the family (Shanafelt et al., 2020). High levels of anxiety are related to the stress experienced by nurses during the Covid-19 pandemic (Mo et al., 2020).

Having direct contact with Covid-19 patients, health care workers (HCWs) are more exposed to traumatic events such as patients' suffering and deaths (Pappa et al., 2020), which could further amplify their anxiety, stress, and depression. For this reason, it is important to carry out an investigation 
Fitria Endah janitra: Perceived Stigma, Psychological Response, and Nurse Coping in The Covid-19 Pandemic

about the stigma, psychological response and coping of nurses during Covid-19 pandemic in Indonesia.

\section{Method}

This study was designed as a descriptive quantitative study to describe stigma, depression, anxiety, stress and coping of nurses in Covid-19 pandemic in Indonesia. This research had passed the ethical board of RS. Islam Sultan Agung Semarang with number 180/B1/FIK-SA/IV/2020. The population of this study were all nurses caring for Covid-19 patients in Indonesia. After calculating the sample size using the Slovin formula, the sample size was 509. 509 respondents have provided written informed consent prior to data collection. Data collections were taken from April 11 until April 20, 2020. Respondents filled out a questionnaire using a Google-form sent via WhatsApp application which was distributed randomly throughout Indonesia. Data analysis was implemented using a computer program. Proportion of stigma, depression, anxiety, stress and coping were determined.

For stigma, modification of Berger Stigma Scale was used (Berger et al., 2001). This tool consisted of a total 12 question in personalized stigma factors. A 4-point likert scale was used, ranging from 1 ('Strongly Disagree') to 4 ('Strongly Agree'), which means the higher the score, the greater the stigma.

For depression, anxiety and stress, modifications of DASS-21 questionnaire was used (Osman et al., 2012). This tool consisted of a total 15 question with proportional questions in each depression, anxiety, and stress subscales. A 4-point likert scale was used, ranging from 0 ('Never') to 3 ('Almost Always'), which means the higher the score, the greater depression, anxiety and stress.

For Coping, modification of the Brief Of Cope questionnaire was used (Carver, 1997). This tool consisted of a total 15 questionnaire with proportional question in each subscales (problem focused coping, emotional focused coping, less useful coping). A 4-point likert scale was used, ranging from 1 ('Never') to 4 ('Always'), which means the higher the score, the greater score in each subscales. The questionnaires used in this study have been proven valid and reliable after being tested on 30 nurses treating Covid-19 patients with a Cronbach Alpha value as follows: modified Berger Stigma Scale 0.952; modified DASS 0.928; and modified Brief of Cope 0.753.

\section{Results}

\section{General Characteristics}

General characteristics of respondents in this study can be seen in table 1 . Most of the respondents were 26-35 years old (52.1\%), female $(61.5 \%)$, and worked in governmentowned hospitals $(48.3 \%)$.

Table 1 General Characteristics of Respondents

\begin{tabular}{lc}
\hline \multicolumn{1}{c}{ General Characteristics } & Frequency (\%) \\
\hline Ages & \\
$17-25$ years & $73(14.3 \%)$ \\
$26-35$ years & $265(52.1 \%)$ \\
$36-45$ years & $133(26.1 \%)$ \\
$46-55$ years & $38(7.5 \%)$ \\
Gender & \\
Female & $313(61.5 \%)$ \\
Male & $196(38.5 \%)$ \\
Work Unit & \\
Public health center & $84(16.5 \%)$ \\
Government-owned hospitals & $246(48.3 \%)$ \\
Private hospital & $154(30.3 \%)$ \\
Others & $25(4.9 \%)$ \\
\hline
\end{tabular}


Fitria Endah janitra: Perceived Stigma, Psychological Response, and Nurse Coping in The Covid-19 Pandemic

Table 2 Proportion of Stigma, Depression, Anxiety and Stress

\begin{tabular}{|c|c|}
\hline Variabel & Frequency (\%) \\
\hline \multicolumn{2}{|l|}{ Stigma } \\
\hline Stigmatized & $231(45.4 \%)$ \\
\hline Not stigmatized & $278(54.6 \%)$ \\
\hline \multicolumn{2}{|l|}{ Depression } \\
\hline Depressed & $274(46.2 \%)$ \\
\hline Not depressed & $235(53.8 \%)$ \\
\hline \multicolumn{2}{|l|}{ Anxiety } \\
\hline Anxious & $180(35.4 \%)$ \\
\hline Not anxious & $329(64.6 \%)$ \\
\hline \multicolumn{2}{|l|}{ Stress } \\
\hline Stressed & $209(41.1 \%)$ \\
\hline Not stressed & $300(58.9 \%)$ \\
\hline
\end{tabular}

\section{Proportion of Stigma, Depression, Anxiety and Stress}

Data on stigma, depression, anxiety, and stress were classified into 2 categories based on the median cut-off point value because the data were not normally distributed as can be seen in table 2 . As many as 231 respondents (45.4\%) felt stigmatized, 274 respondents (46.2\%) were depressed, and 209 respondents $(41.1 \%)$ were stressed.

\section{Proportion of Coping}

The coping variables are classified into 3 categories, namely problem focused coping, emotional focused coping, and avoidance coping according to the question category in the questionnaire. Most of the respondents $(65.8 \%)$ have practiced problem focused coping.

Table 3 Proportion of Coping

\begin{tabular}{lc}
\hline \multicolumn{1}{c}{ Variabel } & Frequency (\%) \\
\hline Coping & \\
Problem focused coping & $335(65.8 \%)$ \\
Emotional focused coping & $157(30.8 \%)$ \\
Less Useful coping & $17(3.3 \%)$ \\
\hline
\end{tabular}

\section{Discussion}

This research was conducted at the beginning of the Covid-19 pandemic in Indonesia. From 509 respondents, $45.4 \%$ (231) of respondents felt stigmatized. When compared with our study, a study in India showed 54.6\% of respondents also had a high perceived stigma score (Uvais et al., 2020). Perceived stigma arises when a person is aware of the social stigma against their group, and then internalizes it so that it can result in a loss of self-confidence and self-efficacy (Vogel et al., 2013). The social stigma in the Covid-19 pandemic is caused by unscientific beliefs and a lack of public knowledge (Bagcchi,
2020).

In this study, $46.2 \%$ of respondents experienced depression. Nurses have to face enormous workload and high-risk infection, which may lead to mental health problems such as anxiety or depression (Kang et al., 2020). The depression level of health workers (doctors and nurses) is getting higher along with the increasing level of hospitals in the care of Covid-19 patients (Liu et al., 2020a).

$35.4 \%$ of respondents (180 people) in this study experienced anxiety. Anxiety is defined as a state of anxiousness or worry resulting from the anticipation of a real or perceived threat in a situation (Spielberger, 2010). Anxiety creates psychological problems for 
Fitria Endah janitra: Perceived Stigma, Psychological Response, and Nurse Coping in The Covid-19 Pandemic

nurses, which reduces the quality of service during the pandemic (Wahyuningsih et al., 2020). Anxiety is commonly experienced by health workers who are directly involved in the care of Covid-19 patients and potentially affecting nurses' well-being and work performance (Labrague \& Santos, 2020).

The main source of anxiety in nurses during the Covid-19 pandemic was fear of becoming infected or unknowingly infecting others, lack of personal protective equipment (PPE), fear of harbouring the novel coronavirus at work, lack of access to Covid-19 testing, fear of transmitting the virus at work, doubt that their institution would support them if they became infected, lack of access to childcare facilities during lockdown, fear of being deployed in an unfamiliar ward or unit and lack of accurate information on the disease (Mo et al., 2020; Shanafelt et al., 2020).

In this study, $41.1 \%$ of respondents (209 people) experienced stress. During pandemic, nurses are faced with a work environment with high job demands, high work pressure and symptoms of physical and psychological stress that can affect their health and wellbeing (Mo et al., 2020). Previous studies have shown that nurses with high levels of stress can be triggered by frustration, depression and other psychological and emotional disorders (Mo et al., 2020; Teles et al., 2014).

Coping is defined as a person's cognitive and behavioural efforts in response to stressors that determine how those stressors will affect physical and emotional well-being (Lazarus et al., 1984). In this study, 65.8\% of respondents (335 people) used adaptive coping, namely problem focused coping. The purpose of problem-focused coping is to solve the problem or take action to change the status quo (Huang et al., 2020). Problemfocused coping was associated with better mental health and emotion-focused coping was associated with reduced mental health (Chang et al., 2007).

\section{Conclusion}

The nurse may face a greater risk of exposure to Covid-19 patients as they spend more time on wards, provide direct care to patients, and are responsible for the collection of sputum for virus detection (Liu et al., 2020b). This condition might provoke stress, anxiety, and depression that can be seen from the results of this study. Social support can be an important factor in reducing psychological responses to nurses. Strengthening social support among nurses can mitigate the impact of work pressure on health (Mo et al., 2020; Ozbay et al., 2007). Nurses also have to maintain relationships with family and colleagues to get spiritual support to alleviate their mental burden. To avoid stigma against health workers, especially nurses, it is necessary to educate the community so that it does not give a bad stigma because it can affect the psychological condition of nurses.

\section{References}

Bagcchi, S. (2020, July). Stigma during the Covid-19 pandemic. Lancet. September 21, 2020, from https://www.thelancet.com/pdfs/ journals/laninf/PIIS1473-3099(20)30498-9. pdf

Berger, B. E., Ferrans, C. E., \& Lashley, F. R. (2001). Measuring stigma in people with HIV: Psychometric assessment of the HIV stigma scale. Research in Nursing \& Health, 24(6), 518-529. https://doi.org/10.1002/ nur. 10011.

Carver, C. S. (1997). You want to measure coping but your protocol' too long: Consider the brief cope. International Journal of Behavioral Medicine, 4(1), 92-100. https:// doi.org/10.1207/s15327558ijbm0401_6.

Chang, E. M. L., Bidewell, J. W., Huntington, A. D., Daly, J., Johnson, A., Wilson, H., Lambert, V. A., \& Lambert, C. E. (2007). A survey of role stress, coping and health in Australian and New Zealand hospital nurses. International Journal of Nursing Studies, 44(8), 1354-1362. https://doi.org/10.1016/j. ijnurstu.2006.06.003.

Chew, N. W. S., Lee, G. K. H., Tan, B. Y. Q., Jing, M., Goh, Y., Ngiam, N. J. H., Yeo, L. L. L., Ahmad, A., Ahmed Khan, F., Napolean Shanmugam, G., Sharma, A. K., Komalkumar, R. N., Meenakshi, P. V., 
Fitria Endah janitra: Perceived Stigma, Psychological Response, and Nurse Coping in The Covid-19 Pandemic

Shah, K., Patel, B., Chan, B. P. L., Sunny, S., Chandra, B., Ong, J. J. Y., ... Sharma, V. K. (2020). A multinational, multicentre study on the psychological outcomes and associated physical symptoms amongst healthcare workers during Covid-19 outbreak. Brain, Behavior, and Immunity, 88(April), 559-565. https://doi.org/10.1016/j.bbi.2020.04.049.

Elvina, L. (2020, April 10). Viral! Jenazah Perawat yang Terjangkit Corona di Semarang Ditolak Warga. (Viral! A nurse corpse contracted with Coronavirus in Semarang was rejected by residents). Kompas.TV. Retrieved August 24, 2020, from https:// www.kompas.tv/article/75553/viral-jenazahperawat-di-semarang-ditolak-warga.

Goffman, E. (1963). Stigma; Notes on the Management of Spoiled Identity. PrenticeHall.

He, X., Lau, E. H. Y., Wu, P., Deng, X., Wang, J., Hao, X., Lau, Y. C., Wong, J. Y., Guan, Y., Tan, X., Mo, X., Chen, Y., Liao, B., Chen, W., Hu, F., Zhang, Q., Zhong, M., Wu, Y., Zhao, L., ... Leung, G. M. (2020). Temporal dynamics in viral shedding and transmissibility of Covid-19. Nature Medicine, 26(5), 672-675. https://doi.org/10.1038/s41591-020-0869-5.

Huang, L., Lei, W., Xu, F., Liu, H., \& Yu, L. (2020). Emotional responses and coping strategies in nurses and nursing students during Covid-19 outbreak: A comparative study. PLoS One, 15(8). https://doi. org/10.1371/journal.pone.0237303.

Kang, L., Li, Y., Hu, S., Chen, M., Yang, C., Yang, B. X., Wang, Y., Hu, J., Lai, J., Ma, X., Chen, J., Guan, L., Wang, G., Ma, H., \& Liu, Z. (2020). The mental health of medical workers in Wuhan, China dealing with the 2019 novel coronavirus. The Lancet Psychiatry, 7(3), e14. https://doi.org/10.1016/ S2215-0366(20)30047-X.

Koh, D., Lim, M. K., Chia, S. E., Ko, S. M., Qian, F., Ng, V., Tan, B. H., Wong, K. S., Chew, W. M., Tang, H. K., Ng, W., Muttakin, Z., Emmanuel, S., Fong, N. P., Koh, G., Kwa, C. T., Tan, K. B.-C., \& Fones, C. (2005). Risk perception and impact of severe acute respiratory syndrome (SARS) on work and personal lives of healthcare workers in Singapore. Medical Care, 43(7), 676-682. https://doi.org/10.1097/01. mlr.0000167181.36730.cc.

Labrague, L. J., \& Santos, J. A. A. (2020). COVID-19 anxiety among front-line nurses: Predictive role of organisational support, personal resilience and social support. Journal of Nursing Management, jonm 8, 1653-1661. https://doi.org/10.1111/jonm.13121.

Lazarus, Richard, \& Folkman, S. (1984). Stress, Appraissal, and Coping. Springer Pub. Co.

Li, Q., Guan, X., Wu, P., Wang, X., Zhou, L., Tong, Y., Ren, R., Leung, K. S. M., Lau, E. H. Y., Wong, J. Y., Xing, X., Xiang, N., Wu, Y., Li, C., Chen, Q., Li, D., Liu, T., Zhao, J., Liu, M., ... Feng, Z. (2020). Early transmission dynamics in Wuhan, China, of novel coronavirus-infected pneumonia. New England Journal of Medicine, 382(13), 1199-1207. https://doi.org/10.1056/

NEJMoa2001316

Liu, Z., Han, B., Jiang, R., Huang, Y., Ma, C., Wen, J., Zhang, T., Wang, Y., Chen, H., \& Ma, Y. (2020a). Mental Health Status of Doctors and Nurses During Covid-19 Epidemic in China. SSRN Electronic Journal. https://doi. org/10.2139/ssrn.3551329

Liu, Z., Han, B., Jiang, R., Huang, Y., Ma, C., Wen, J., Zhang, T., Wang, Y., Chen, H., \& Ma, Y. (2020b). Mental Health Status of Doctors and Nurses During Covid-19 Epidemic in China. SSRN Electronic Journal. https://doi. org/10.2139/ssrn.3551329

Mo, Y., Deng, L., Zhang, L., Lang, Q., Liao, C., Wang, N., Qin, M., \& Huang, H. (2020). Work stress among Chinese nurses to support Wuhan in fighting against Covid-19 epidemic. Journal of Nursing Management, 28(5), 1002-1009. https://doi.org/10.1111/ jonm.13014

Ornell, F., Halpern, S. C., Kessler, F. H. P., \& Narvaez, J. C. de M. (2020). The impact of the COVID-19 pandemic on the mental health of 
Fitria Endah janitra: Perceived Stigma, Psychological Response, and Nurse Coping in The Covid-19 Pandemic

healthcare professionals. Cadernos de Saúde Pública, 36(4). https://doi.org/10.1590/0102311x00063520

Osman, A., Wong, J. L., Bagge, C. L., Freedenthal, S., Gutierrez, P. M., \& Lozano, G. (2012). The Depression Anxiety Stress Scales-21 (DASS-21): Further Examination of Dimensions, Scale Reliability, and Correlates. Journal of Clinical Psychology, 68(12), 1322-1338. https://doi.org/10.1002/ jclp.21908

Ozbay, F., Johnson, D. C., Dimoulas, E., Morgan, C. A., Charney, D., \& Southwick, S. (2007). Social support and resilience to stress: from neurobiology to clinical practice. Psychiatry (Edgmont (Pa.: Township)), 4(5), 35-40. http://www.ncbi.nlm.nih.gov/ pubmed/20806028.

Pappa, S., Ntella, V., Giannakas, T., Giannakoulis, V. G., Papoutsi, E., \& Katsaounou, P. (2020). Prevalence of depression, anxiety, and insomnia among healthcare workers during the Covid-19 pandemic: A systematic review and metaanalysis. Brain, Behavior, and Immunity. https://doi.org/10.1016/j.bbi.2020.05.026

Satgas Penanganan Covid-19. (2020). Peta Sebaran. (Task Force for Handling Covid-19. Distribution Map). Retrieved August 28, 2020, from https://covid19.go.id/petasebaran

Shanafelt, T., Ripp, J., \& Trockel, M. (2020). Understanding and addressing sources of anxiety among health care professionals During the Covid-19 Pandemic. JAMA, 323(21), 2133. https://doi.org/10.1001/ jama.2020.5893

Siordia, J. A. (2020). Epidemiology and clinical features of Covid-19: A review of current literature. Journal of Clinical Virology, 127. https://doi.org/10.1016/j. jcv.2020.104357

Somantri, I., \& Yudianto, K. (2018). Quality of nurse work life in Pangandaran health center. Jurnal Keperawatan Padjadjaran (Padjadjaran Nursing Journal), 6(3). https:// $\underline{\text { doi.org/10.24198/jkp.v6i3.621 }}$

Spielberger, C. D. (2010). State-trait anxiety inventory. In The Corsini Encyclopedia of Psychology. John Wiley \& Sons, Inc. https://doi.org/10.1002/9780470479216. corpsy0943.

Suyudi. (2020, April 27). 3 Perawat diusir dari kos, $R S$ di Solo jemput pakai ambulans (3 nurses evicted from their kost, Solo Hospital picking them up using ambulance). CNN Indonesia. Retrieved Ausgust 24, 2020, from https://www.cnnindonesia.com/ nasional/20200427164601-20-497756/3perawat-diusir-dari-kos-rs-di-solo-jemputpakai-ambulans

Teles, M. A., Barbosa, M., Vargas, A. M., Gomes, V., e Ferreira, E., Martins, A. M., \& Ferreira, R. (2014). Psychosocial work conditions and quality of life among primary health care employees: a cross sectional study. Health and Quality of Life Outcomes, 12(1), 72. https://doi.org/10.1186/1477-7525-12-72

Uvais, N. A., Aziz, F., \& Hafeeq, B. (2020). Covid-19-related stigma and perceived stress among dialysis staff. Journal of Nephrology, 0123456789, 19-20. https://doi.org/10.1007/ s40620-020-00833-x.

Vogel, D. L., Bitman, R. L., Hammer, J. H., \& Wade, N. G. (2013). Is stigma internalized? The longitudinal impact of public stigma on self-stigma. Journal of Counseling Psychology, 60(2), 311-316. https://doi. org/10.1037/a0031889

Wahyuningsih, I. S., Janitra, F. E., Hapsari, R., Sarinti, S., Mahfud, M., \& Wibisono, F. (2020). The Nurses' Experience during the Caring of Coronavirus (Covid-19) Patients: A Descriptive Qualitative Study. Jurnal Keperawatan Padjadjaran, 8(3). https://doi. org/10.24198/jkp.v8i3.1559

Worldometers info. (2020, February 29). Coronavirus Disease 2019. Retrieved June 9， $2020 \mathrm{https}: / / \mathrm{www}$.worldometers. info/coronavirus/feb-2020-news-updatescovid19/ 
Fitria Endah janitra: Perceived Stigma, Psychological Response, and Nurse Coping in The Covid-19 Pandemic

Zheng, R., Zhou, Y., Fu, Y., Xiang, Q., Cheng, F., Chen, H., Xu, H., Fu, L., Wu, X., Feng, M., Ye, L., Tian, Y., Deng, R., Liu, S., Jiang, Y., Yu, C., \& Li, J. (2021). Prevalence and associated factors of depression and anxiety among nurses during the outbreak of Covid-19 in China: A cross-sectional study. International Journal of Nursing Studies, 114, 103809 . https://doi.org/10.1016/j. ijnurstu.2020.103809 